\title{
PHYTOHEMAGGLUTININS: A NEW CLASS OF METALLOPROTEINS. ISOLATION, PURIFICATION, AND SOME PROPERTIES OF THE LECTIN FROM PHASEOLUS LUNATUS
}

\author{
W.GALBRAITH and I.J.GOLDSTEIN \\ Department of Biological Chemistry \\ The University of Michigan \\ Ann Arbor, Michigan 48104, U.S.A.
}

Received 26 June 1970

\section{Introduction}

Phytohemagglutinins (lectins) are carbohydratebinding globulin proteins found in the seeds of a wide variety of leguminous plants $[1,2]$. These seed proteins provide a unique opportunity for the investigation of homogeneous combining sites, a possibility not yet realized with antibodies. The specificities of a few lectins have been studied in some detail [3-6].

Concanavalin A (con A) the phytohemagglutinin of the jack bean (Canavalia ensiformis) is the only purified lectin which is not a glycoprotein and for which a metal requirement has been established conclusively [7-9]. There have been no reports concerning the metal requirements of other phytohemagglutinins, although reference has been made to the fact that ethylenediaminetetraacetate (EDTA) abolishes the agglutinating and mitogenic stimulating properties of PHA, a crude extract of Phaseolus vulgaris, variously referred to as wax bean or kidney bean $[10,11]$.

The lectin of the lima bean, Phaseolus lunatus, studied extensively in the form of its crude extracts or partially purified preparations [12-14] , has been shown to be specific for type A human red blood cells and to be specifically inhibited by $N$-acetyl-D-galactosamine (GalNAc). Recently, Gould and Scheinberg [15] published an isolation procedure for the lima bean phytohemagglutinin and reported some of its physical and chemical properties. Two active components were found - one with twice the molecular weight of the other.
This communication describes a total purification of the lima bean lectin based on its specific adsorption to insoluble polyleucyl Type A blood group substance, followed by resolution into two active components by molecular sieve chromatography. We also describe: (a) the nature of the carbohydrate moiety of the lima bean phytohemagglutinin; (b) the specific interaction of this carbohydrate moiety with con $\mathrm{A} ;(\mathrm{c})$ some specificity studies of the lectin combining sites; (d) the absolute requirement of metal for the carbohydrate-binding and agglutinating activity of the lima bean lectin.

The metal content and its necessity for activity of the purified phytohemagglutinins of the wax bean (Phaseolus vulgaris) and the soybean (Glycine max) are also described.

\section{Materials and methods}

Two preparations of human ovarian cyst blood group substance were the gift of Dr. R.Poretz and Prof. W.Watkins, Lister Institute, London. Human red blood cells (Type A, B and O) were kindly provided by Dr. H.Oberman, University of Michigan. All chemicals used were of reagent grade or best quality available.

\subsection{Purification of the lima bean lectin}

Finely ground Sieva lima beans, Phaseolus lunatus, (W.Atlee Burpee Co., Clinton, Iowa) were extracted 
Table 1

Purification scheme for lima bean lectin.

\begin{tabular}{|c|c|c|c|c|c|}
\hline & $\begin{array}{l}\text { Protein concn. }{ }^{\mathrm{a}} \\
\quad(\mathrm{mg} / \mathrm{ml})\end{array}$ & $\begin{array}{l}\text { Volume } \\
(\mathrm{ml})\end{array}$ & $\begin{array}{c}\text { Total } \\
\text { protein }\end{array}$ & Titer & $\begin{array}{l}\text { Specificb } \\
\text { activity }\end{array}$ \\
\hline $\begin{array}{l}\text { Combined } \\
\text { extracts }\end{array}$ & 27.4 & 3,685 & $101 \mathrm{~g}$ & 2,048 & 75 \\
\hline $60^{\circ}$ Supernatant & 24 & 3,260 & $78 \mathrm{~g}$ & 2,048 & 85 \\
\hline $\begin{array}{l}\text { pH } 4.0 \\
\text { Supernatant }\end{array}$ & 22 & 3,352 & $74 \mathrm{~g}$ & 2,048 & 93 \\
\hline $\begin{array}{l}40 \rightarrow 60 \% \\
\left(\mathrm{NH}_{4}\right)_{2} \mathrm{SO}_{4} \text { ppt. }\end{array}$ & 63 & 214 & $13.5 \mathrm{~g}$ & 65,536 & 1,040 \\
\hline $\begin{array}{l}\text { PLA eluent } \\
\text { (from } 3.4 \mathrm{~g} \text { ) } \\
40 \rightarrow 60 \% \\
\left(\mathrm{NH}_{4}\right)_{2} \mathrm{SO}_{4} \mathrm{ppt} .\end{array}$ & 6.8 & 18.8 & $128 \mathrm{mg}$ & 32,768 & 4,820 \\
\hline $\begin{array}{l}\text { G-200 column: } \\
\text { Component I } \\
\text { Component II } \\
\text { Component III }\end{array}$ & $\begin{array}{r}0.1 \\
3.2 \\
12.5\end{array}$ & $\begin{array}{r}31 \\
5.4 \\
5.5\end{array}$ & $\begin{array}{r}3 \mathrm{mg} \\
18 \mathrm{mg} \\
106 \mathrm{mg}\end{array}$ & $\begin{array}{r}8 \\
16,384 \\
16,384\end{array}$ & $\begin{array}{r}80 \\
5,100 \\
1,310\end{array}$ \\
\hline
\end{tabular}

a Determined by Biuret method [22] .

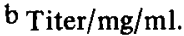

twice for 2 days at $4^{\circ}$ with 4 times their weight of $0.15 \mathrm{M} \mathrm{NaCl}$. The extracts were combined and centrifuged. Purification (table 1) includes: (a) heat treatment $\left(60^{\circ}\right.$ for $\left.20 \mathrm{~min}\right)$, the precipitate being discarded;(b) adjustment of the supernatant solution to $\mathrm{pH} 4$ and centrifugation; (c) $\left(\mathrm{NH}_{4}\right)_{2} \mathrm{SO}_{4}$ fractionation at $\mathrm{pH} 6.8$ (40-60\% saturation fraction isolated); (d) specific adsorption at $4^{\circ}$ of dialyzed $\left(\mathrm{NH}_{4}\right)_{2} \mathrm{SO}_{4}$ fraction in $0.15 \mathrm{M} \mathrm{NaCl}$ and $0.01 \mathrm{M}$. Na phosphate buffer pH 7.0 (PBS) to a column of type A human cyst material insolubilized by treatment with leucine $N$-carboxyanhydride (PLA column) [16] . Protein $(96 \%)$ inactive toward Type A cells passed through the column. GalNAc, $0.4 \mathrm{M}$ in $0.15 \mathrm{M} \mathrm{NaCl}$, displaced protein which agglutinated Type A cells. The lectin preparation, dialyzed free of GalNAc, was fractionated by recycling gel filtration on Sephadex G-200 at $20^{\circ}$ to give a small quantity of an inactive component $I$, and two active components, II and III which were concentrated individually on a Model 52 Amicon ultrafiltration cell (UM-10 membrane).

\subsection{Removal of metal from lectins}

Each lectin $(5 \mathrm{mg})$ in $10 \mathrm{ml}$ of $1 \mathrm{mM}$ heavy metal- free $\mathrm{NaCl}$ ("MF" $\mathrm{NaCl}$ ) was dialyzed against 4 changes of $0.1 \mathrm{M}$ EDTA followed by dialysis against $1 \mathrm{mM}$ "MF" $\mathrm{NaCl}$. Following assays for activity and protein, the samples were dialyzed successively aga inst $1 \mathrm{M}$ acetic acid, ( $\mathrm{pH} \mathrm{2.2)}$ and $1 \mathrm{mM}$ " $\mathrm{MF}$ " $\mathrm{NaCl}$ to give "metal-free" lectin.

\subsection{Reactivation of lectins}

The "metal-free" lectins ( $2 \mathrm{ml}$ containing approx. $1 \mathrm{mg}$ protein) were dialyzed against a solution contain. ing $1 \mathrm{mM} \mathrm{MnCl} 2$ and $1 \mathrm{mM} \mathrm{CaCl}_{2}$ and then against $1 \mathrm{mM}$ "MF" $\mathrm{NaCl}$ to remove unbound metals.

\subsection{Analytical procedures}

Hemagglutination was conducted by serial dilution of lectin in PBS. A 2\% suspension of freshly washed Type A red blood cells in PBS was used to react with lectin unless otherwise stated. Agglutinations were recorded after standing for $24 \mathrm{hr}$ and activity expressed as titer, the reciprocal of the greatest dilution at which agglutination occurred.

Quantitative precipitin analyses were performed employing a total volume of $200 \mu \mathrm{l}$. The tubes containing $2 \mu$ moles phosphate buffer (pH 7.0), 28.5 


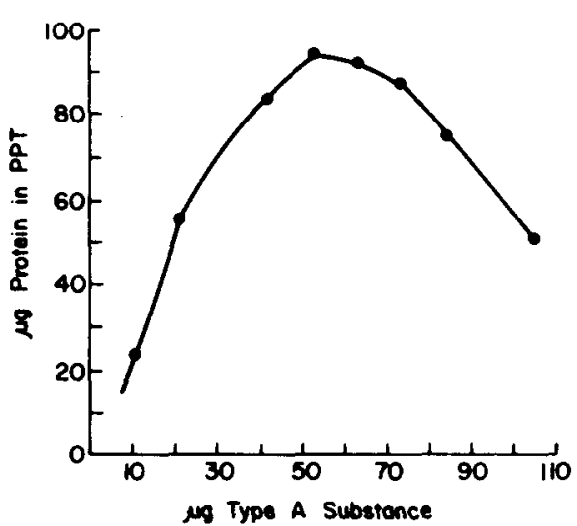

Fig. 1. Quantitative precipitation curve produced by the interaction of component III with blood group A substance. Each tube contained $110 \mu \mathrm{g}$ component III.

$\mu$ moles $\mathrm{NaCl}$, approx. $100 \mu \mathrm{g}$ lectin and varying amounts of Type A substance were incubated for 2 days at $20^{\circ}$. Total protein in the washed precipitates was determined by a semi-micro Lowry procedure [17]. Neutral sugar was determined by the phenol$\mathrm{H}_{2} \mathrm{SO}_{4}$ method [18] with mannose as standard, and by gas-liquid chromatography [19] . Samples of con $A$, soybean lectin and wax bean lectin were obtained as described previously [20]. Quantitative precipitations with concanavalin A were performed as described earlier [21] but using $1 / 4$ scale and determining protein by the micro Lowry method as above. $\mathrm{Mn}^{2+}$ and $\mathrm{Ca}^{2+}$ were determined by atomic absorption on Beckman Model 440 and Instrumentation Laboratories Model 153.

\section{Results and discussion}

\subsection{Purification}

It is apparent (table 1) that the major purification step involves specific adsorption to the PLA column followed by elution with GalNAc. Sephadex G-200 recycling chromatography resulted in the isolation of 3 components, numbered in order of elution from the column. Component I displayed very low hemagglutinating activity and may represent a small amount of impurity. Component II has a specific activity more than twice that of Component III.

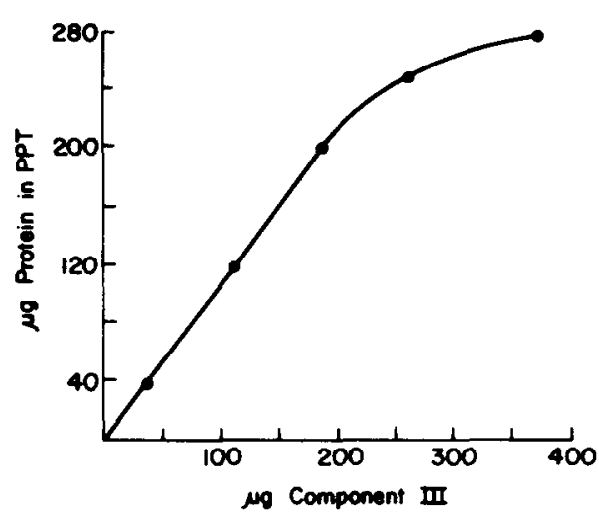

Fig. 2. Quantitative precipitation curve produced by the interaction of concanavalin $\mathrm{A}$ with component III. Each tube contained $219 \mu \mathrm{g}$ concanavalin A.

\subsection{Purity}

Components II and III each gave a single band on disc gel electrophoresis at $\mathrm{pH} 9.5$ and $\mathrm{pH} 4.3$. At $\mathrm{pH}$ 9.5 both protein components ran as diffuse bands, whereas at $\mathrm{pH} 4.3$ both components afforded sharp bands with component III having greater mobility. Molecular weight determinations using calibrated Sephadex G-200 columns showed component III to have an apparent molecular weight of 90,000; component II approx. 180,000 . These are in contrast to the molecular weights of 138,000 and 269,000 reported by Gould and Scheinberg [15] for the lima bean lectins obtained by a different purification procedure and different molecular weight method. Gould and Scheinberg [15] suggested that the two hemagglutinating components of the lima bean are related proteins composed of identical subunits of molecular weight 31,000 . Our amino acid analyses of component III are in excellent agreement with those of Gould and Scheinberg. We have confirmed the absence of methionine and the presence of 2 moles of $1 / 2$ cystine per $31,000 \mathrm{~g}$ of protein.

\subsection{Activity}

Two indices of activity were used to study the lima bean lectin, (a) hemagglutination and (b) precipitation with blood group A substance. As shown in table 1, the lectins exhibited a very high titer for Type A cells. Only very concentrated solutions of each lima bean lectin component agglutinated Type B cells with a 
Table 2

Metal content and activity of some lectins.

\begin{tabular}{lrll}
\hline Lectin & $\begin{array}{c}\text { Specific } \\
\text { activity }\end{array}$ & $\% \mathrm{Mn}^{2+}$ & $\% \mathrm{Ca}^{2+}$ \\
\hline $\begin{array}{l}\text { Soybean } \\
\text { native } \\
\text { "metal-free" }\end{array}$ & 710 & .035 & .447 \\
reactivated & 92 & .005 & .362 \\
& 276 & .024 & .333 \\
$\begin{array}{l}\text { Wax bean } \\
\text { native }\end{array}$ & & & \\
"metal-free" & 160 & .011 & .206 \\
reactivated & 37 & .007 & .375 \\
& 125 & .015 & .875 \\
Lima bean & & & \\
native & & & \\
"metal-free" & 1,370 & .052 & .166 \\
reactivated & 334 & .005 & .143 \\
\hline
\end{tabular}

a Both components have approximately the same metal content. Component III was used in this experiment.

typical specific activity of 15 compared to a specific activity of 5,100 against Type A cells. Neither lima bean lectin component agglutinated Type $\mathbf{O}$ cells nor reacted with Type $\mathrm{H}$ substance from hog submaxillary mucin. As expected the lima bean lectins reacted very strongly with Type A blood group substance from either hog gastric mucin or human ovarian cyst [13]. Fig. 1 shows a typical precipitin curve of component III against human Type A blood group substance. About 80 to $90 \%$ of the lectin added is precipitated under the conditions described. Component II reacted similarly but reached equivalence and was inhibited earlier. More precipitation occurred at $20^{\circ}$ or $37^{\circ}$ than at $4^{\circ}$ [cf 21]. Similar to concanavalin $\mathrm{A}$, the lima bean lectin has a broad $\mathrm{pH}$ optimum (pH 4-9.4) with maximum activity around $\mathrm{pH} 7$.

GalNAc is a good inhibitor of both the hemagglutination and the precipitation reactions, whereas ManNac and GlcNAc are not inhibitors at the level which gives maximal inhibition by GalNAc. Methyl 2-acetamido-2-deoxy- $\alpha$-D-galactopyranoside is a threefold more effective inhibitor than GalNAc.

Lime bean lectin was reported by Gould and Scheinberg [15] to contain $4 \%$ carbohydrate (indole method). Using the phenol- $\mathrm{H}_{2} \mathrm{SO}_{4}$ method, we found $3-4 \%$ carbohydrate in both component II and component III. Further investigation of the carbohydrate moiety showed the major sugar components to be mannose and glucosamine, with lesser amounts of xylose and fucose. The presence of trace quantities of glucose and arabinose may represent impurities.

When reacted with con $\mathrm{A}$, each lima bean lectin (components II and III) gave a strong precipitation line in agar gel double diffusion. The precipitin band dissolved slowly in $0.1 \mathrm{M} \mathrm{N}$-methyl- $\alpha$-mannoside. Con A reacts with lima bean lectin to give a precipitin curve (fig. 2) similar to those given by the soybean and wax bean lectins [20]. These results, together with the demonstrated presence of mannose as a major sugar component, suggest the presence of multiple, terminal, non-reducing $\alpha$-D-mannopyranosyl residues.

The activity of each lima bean lectin was inhibited by EDTA, which suggested the necessity of metal ion for the activity of the lectin. The two phytohemagglutinins studied in our laboratory, con A and lima bean lectin, required $\mathrm{Mn}^{2+}$ for activity; we therefore tested two other lectins, purified to homogeneity, for metal content. Table 2 shows clearly that all lectins examined contained $\mathrm{Mn}^{2+}$ and $\mathrm{Ca}^{2+}$. $\mathrm{Mn}^{2+}$, readily removed by dialysis against EDTA and acetic acid, is apparently required for activity, whereas the role of $\mathrm{Ca}^{2+}$, which is not removed under these conditions, is not known. Difco PHA-P, a partially purified kidney bean lectin also contains $\mathrm{Mn}^{2+}$ and $\mathrm{Ca}^{2+}$. These results suggest that all phytohemagglutinins probably depend upon metal ion for their activity.

\section{Acknowledgements}

This research was supported by N.I.H. Grant AM-10171. We thank Dr. G.W.Jourdian for assistance in GLC analysis of sugars, Dr. C.H.Williams for amino acid analyses, Dr. D.Aminoff for gifts of Type A and $\mathrm{H}$ blood group substances from hog mucin, and $\mathrm{Mr}$. D.Baty and Mr. J.Alstadt for metal analyses.

\section{References}

[1] J.M.Dechary, Vox Sanguinis 15 (1968) 401.

[2] W.C.Boyd, Vox Sanguinis 8 (1963) 1.

[3] L.L.So and I.J.Goldstein, J. Immunol. 99 (1967) 158.

[4] R.G.Drysdale, P.R.Henick and D.Franks, Vox Sanguinis 15 (1968) 194.

[5] M.E.Etzler and E.A.Kabat, Biochemistry 9 (1970) 869. 
[6] W.M.Watkins and W.T.J.Morgan, Vox Sanguinis 7 (1962) 120.

[7] J.B.Sumner and S.F.Howell, J. Biol. Chem. 115 (1936) 583.

[8] A.J.Kalb and A.Levitzki, Biocl.2m. J. 109 (1968) 669.

[9] B.B.L.Agrawal and I.J.Goldstein, Can. J. Biochem. 46 (1968) 1147.

[10] M.Tunis, J. Immunol. 95 (1965) 876.

[11] R.H.Alford, J. Immunol. 104 (1970) 698.

[12] W.T.J.Morgan and M.W.Watkins; Brit. J. Exptl. Pathol. 34 (1953) 94.

[13] W.C.Boyd, E.Shapleigh and M. McMaster, Arch. Biochem. Biophys. 55 (1955) 226.

[14] H.M.Bhatia, Y.C.Kim and W.C.Boyd, Vox Sanguinis 15 (1968) 278.
[15] N.R.Gould and S.L.Scheinberg, Arch. Biochem. Biophys. 137 (1970) 1.

[16] M.E.Kaplan and E.A.Kabat, J. Exptl. Med. 123 (1966) 1061.

[17] R.Mage and S.Dray, J. Immunol. 95 (1965) 525.

[18] M.Dubois, K.A.Gilles, J.K.Hamilton. P.A.Rebers and F.Smith, Anal. Chem. 28 (1956) 350.

[19] W.F.Lehnhardt and R.J.Winzler, J. Chromatogr. 34 (1968) 471.

[20] I.J.Goldstein, L.L.So, Y.Yang and O.C.Callies, J. Immunol. 103 (1969) 695.

[21] L.L.So and I.J.Goldstein, J. Biol. Chem. 242 (1967) 1617.

[22] A.G.Gornall, C.W.Bradawill and M.M.David, J. Biol. Chem. 177 (1949) 751. 